\title{
EXPLORING WRITING STRATEGIES OF BILINGUAL STUDENTS
}

\author{
Romadhon \\ IAIN Syekh Nurjati Cirebon \\ roma.dhon0301@gmail.com \\ Edy Waloyo \\ IAIN Syekh Nurjati Cirebon \\ edyabueza@gmail.com
}

\begin{abstract}
Scholars have long debated the impact of bilingualism on foreign language acquisition. This research was conducted in Senior High School and it involved five bilingual students. They were considered qualified as research subjects because of their language background. The researchers employed observation, documentation of students' writing, and in-depth interview to gain the data. The aims of this research are: to describe the bilingual students' writing performance, to explore writing strategies used by bilingual students, and the reasons why they use those strategies. The research findings suggest that students had a lack of awareness in the organization and content of their writing because they were only concerned about the structure and spelling. Bilingual students used some strategies during writing preparation, while writing, and revision. During the writing preparation, they preferred to write carefully and collaboratively by making a draft, writing scratch before real writing, asking teacher's instruction, and others. While writing, they did not really give attention to readers' perspectives. Also during the revision process, they were concerned to edit words or sentences instead of revising the content or organization.
\end{abstract}

Keywords: bilingualism, students' writing performance, writing strategies

\section{BACKGROUND}

Extensive research on bilingualism or multilingualism has been done in both education and socio-cultural contexts. It is influenced by the globalization era and also immigration. People are required to being communicative in society even in heterogeneous cultures and languages as the aim of bilingualism and multilingualism (Sugiharto, 2015). In line with that, students who come from diverse backgrounds also bring impacts to the effectiveness of the goal itself, in the case of bilingual students.

In the phenomenon of bilingualism, there are three assumptions based on some previous studies. First, bilingualism gives a negative impact on students' intelligence in writing skills. Some studies revealed negative effects or cognitive costs of bilingualism in different aspects including verbal fluency, speech production and picture naming (Ivanova \& Costa, 2008; Sandoval \& et al, 2010), lexical access, and receptive vocabulary (Bialystok, Craik \& Luk, 2008; Ivanova \& Costa, 2008; Bialystok \& Feng, 2009; Hoff, Core, Place, Rumiche, Senor \&Parra, 2012). The negative impacts are receptive vocabulary (Ivanova \& Costa, 2008; Bialystok \& Feng, 2009; Hoff et al., 2012) and lexical access in 
the body of words which is an influencing factor of listening or reading comprehension (Bialystok, 2009; Bialystok et al., 2008).

In this study, multilingualism is a theoretical foundation for gaining research data by firstly analyzing the students' background. Bilingualism or second language connects to students' monolingual for acquiring additional languages by exploring the commonalities in cross-transfer languages (Cenoz et al 2011). Some research suggests that bilingualism is beneficial for students in literacy due to some reasons. First, bilinguals have some background skills for developing their literacy such as oral proficiency, metalinguistic awareness and general cognitive development which all of which are prerequisite skills influencing the literacy proficiency itself. Second, bilinguals also have more opportunities to be advanced because of the transferring skill required in first language readings to other language readings (Bialystok et al., 2015).

A necessary highlight to be examined is the relationship between language-specific factors such as metalinguistic awareness, cross-language transfer, cognitive development, and literacy achievement. Cognitive development is triggered by some factors such as working memory, language-specific factors as orthography demands always change. Bilinguals in possessing literacy gained cognitive development more significant in reading for both languages. They could maximize the background of knowledge in transferring one language to another. Then, bilingualism brings influences to the advanced of writing if there is a similar domain in the writing system (Geva \& Siegel, 2000; Oller \& Eilers, 2002).

Literacy proficiency is important not only for academic purposes but also in individual cognitive development itself (Bialystok et al., 2015; Elaine, 2016). As a productive skill, writing is more difficult than speaking or receptive skill such as listening and reading for some reasons. Students commonly find that they do not know how to start what they want to write and they cannot produce the vocabularies that they need in the writing process. Moreover, writing in some of the education standards used as a qualification for knowing students' cognitive and language development. Then, writing is also used for work placement in some of the countries as one of the requirements of the job (Leki, 2001).

It has been conclusively shown based on the explanation above, the phenomenon of bilingualism brings consideration to students and teachers as education doers. They should understand the benefit and the deleterious of bilingualism to reach learning and teaching goals. Students' knowledge in their first and second languages whether in listening, speaking, or reading will give an outcome in enriching their idea when they want to write a certain topic. Another side, it can be confusing for students because of language commonalities. Because of the complexity of writing, it is necessary to have strategies to overcome the difficulties of it (Flower and Hayes, 1980; Fadilah, 2018). Overall, this research is necessary to gain what are the strategies used by the bilingual students before, while, and after conducting writing as literacy proficiency in learning and teaching English as a foreign language. The reason why the researcher aimed to explore bilingual students' writing performance and strategies is because in process of conducting writing students automatically do language-specific factors from their L1 or L2 to their additional language.

\section{METHOD}


In this study, the researcher employed qualitative descriptive research. Five Senior high school students in the second grade are selected by using questionnaires in preliminary research to gain bilingual students. Later, in data presentation, the five bilingual students were coded by using initial names. The researcher provided three data collections. First is an observation checklist based on the Danielson framework and combined with the theory of direct and hide observation by Sugiono in 2015 to observe teacher, students, and classroom activities in a natural way. The second is writing documentation. The researcher analyzed students' writing performance following the text types on the current teaching syllabus to attain content, organization, mechanic, language use, and vocabulary used. The last is an open-ended interview adapted and modified from Miroslawa (2014). The researcher gained writing strategies in preparation, while, and revision stages done by bilingual students. The primary data was taken from the interview and writing documentation, while observation checklist is used for triangulation data.

\section{FINDINGS}

\section{Bilingual Students' Writing Performance}

Based on writing documentation, the researchers gained data on bilingual students' writing performance.

They were less aware of the organization and content of their writing. They were frequently concerned about the structure and spelling. It caused their writing was not enjoyable to read. It could be seen in \#Z's writing performance:

That places was so cold and comfortable. My family and I went to lots of fun places.

The writer did not explain more what meant by the cold and comfortable place she wrote in the sentence.

They rarely used connection words. It made their writing seemed like one sentence to another sentence are independent, not integrated. It can be observed in \#Z's writing performance:

My vacation was great. I and big family to Kuningan last holiday. My family

and I went to lots of fun places.

In that paragraph, the writer did not put any additional explanation or connection words.

They did not explore the ideas to enrich the content of the writing. They just gave information without putting the reader's position. It can be found in \#R's writing performance;

On Sunday I and family go to Jakarta by car to go Monas. So, after holiday

we feel happy from this vacation to be an unforgettable experience.

The writer did not explore and explain more what looked like Monas was and why he felt happy. That was too short content to make the reader interested.

They frequently used the term and form target language in writing target language. It mentioned in the sentence;

There was a lot of learning that could take even though it was only 4 days of activity in the Al-Bahjah boarding school, but four days an experience in the life. That sentence formed in Indonesia which did not have rule about plural and singular. It should be There were a lot of learnings that could take even though it 
was only 4 days of activity in the Al-Bahjah boarding school, but four days an experience in the life.

The language used is for spoken form. In \#N's writing performance, she wrote;

We joked together, play together, to the point together which seemed like spoken form because there were repetition words. It also found in \#K's writing performance as mentioned; there we were also thought togetherness as prayer 5 in congregation, eating together, dsikir together, all of as doing together, together to create a sense of comfort and a sense of belonging to each other.

There was still inappropriate context in their writing because of transferring a conceptual element from the source language (Indonesia) to the target language (English). The data taken form \#N's writing performance;

In the Cisarua many tour you must visit as Indonesia's zoo, tea's park, puncak, etc. It should be In Cisarua many tour you must visit as like Indonesia's zoo, tea's park, hill, etc.

Table 1. Bilingual Students' Scoring Rubrics of Holiday Recount Text

\begin{tabular}{|c|c|c|c|c|c|c|c|}
\hline NO. & NAME & $\begin{array}{l}\text { CONTENT } \\
(30)\end{array}$ & $\begin{array}{l}\text { LANGUAGE } \\
\text { USE (25) }\end{array}$ & $\begin{array}{l}\text { VOCAB } \\
(20)\end{array}$ & $\begin{array}{l}\text { ORGAN } \\
\text { (20) }\end{array}$ & $\begin{array}{l}\text { MECH } \\
\text { (5) }\end{array}$ & TOT \\
\hline 1. & $\# \mathrm{~N}$ & 28 & 20 & 17 & 18 & 3 & 86 \\
\hline 2. & $\# \mathrm{~W}$ & 28 & 23 & 18 & 15 & 4 & 88 \\
\hline 3. & $\# Z$ & 25 & 20 & 18 & 18 & 3 & 84 \\
\hline 4. & \#R & 23 & 18 & 15 & 15 & 3 & 74 \\
\hline 5. & \#K & 30 & 23 & 18 & 15 & 4 & 90 \\
\hline \multicolumn{2}{|l|}{ Total } & 134 & 104 & 86 & 81 & 17 & 422 \\
\hline \multicolumn{2}{|c|}{ Average } & 26,8 & 20,8 & 17,2 & 16,2 & 3,4 & 84,4 \\
\hline
\end{tabular}

On the other side, the data above showed bilingual students' scores in performing their writing recount text. It could be seen that the highest score of writing performance is \#K who got a total score of 90. The advantage of \#K's writing over other students is she delivered well her ideas. The researcher obtained that \#K's writing was intensive, complex, and explorative. She succeeded to explore the event clearly and comprehensively. Besides that, the lowest score is \#R which only got 74 for the total score. In this case, He was the opposite of \#K's writing content. He did not explore the ideas as well as \#K in delivering the event of his holiday. In his writing just contained a general statement; he did not describe it as well.

Based on the explanation of bilingual students writing performance, bilingual students only focused on spelling and structure but they did not explore the topic related to the writing content. It could be seen from the table, they did not get a maximal score. 


\section{DISCUSSION}

\section{The Writing Strategies Used By Bilingual Students}

The responses of correspondents from the data interview showed that bilingual students in their writing preparation set some activities.

\section{Preparation}

There are some activities that the researcher obtained. It explains below:

\section{Organization}

On the other side, bilingual students have habits to do activities such as: making a comfortable situation, playing English music, preferring to stay in quite a place, and doing the warming up before writing. They assumed that those activities would help them to find and develop the ideas before writing and to make them relax.

\#K also said, "I attend to write when I am in good time".

Furthermore, for bilingual students, the activities in the organization are: looking for writing models on the internet, comparing some writing models, and making an outline in the source language. Those activities were done by bilinguals to make them easier when writing and to know more about the topic. Thet attempted to forget the exact time and event of the topic to make them fast in writing. It is stated by \#W that,

"Yes, on the internet I search for the example and then I follow it in writing".

\section{Content}

Bilingual had some outlining strategies such as understanding teacher's instruction, generating ideas, making a draft, remembering the event in recount text, looking for writing model on internet, using writing plan, making a draft, reading the writing points carefully and using Indonesia as target language to source language of English. They believed that using source language (Indonesia) first helped them to understand the meaning and maximize the writer's comprehension and to make them easier. Besides that, outlining helped them to avoid lost the idea before writing, to make an outline taking a long time because it needs thinking more.

Four bilingual students admitted making a draft before doing real writing; they are \#R, \#W, \#K, and \#Z.

Student \#Z argued that, "Yes I have, before writing I make a draft in different paper first." Meanwhile \#W said that, "I don't directly write down the words, I make a draft in the scratch book then I translate it. It takes more long time yeah because it needs more thinking too."

Four bilingual students generated their ideas before writing the topic in the target language (Indonesia) to translate it into English. It is dominant in bilingual students. \#K added that, "I use Indonesia language first then translate it into English to understand well the content because Indonesia is my daily language." 
Also, \#W said that, "Yes I do. In English still, there is a thing that I don't understand so I prefer Indonesia."

Bilinguals only did simple activities as reading book/ novel/article related to biographical figures. It would help students by providing information, collecting the facts, comparing the information, and enriching vocabulary. \#K said that, "Yes I read the article from the Internet and books. It helps me for comparing which one is trusted resource."

\section{Feedback}

In feedback activities, the students of bilingual needed someone else either their classmate or teacher to make sure their ideas were confirmed by the others. Besides that, Bilingual students attended to ask their classmates to make sure teachers' instruction. As mentioned by \#W, "sometimes I ask my friend what the meant of a thing." The last for obtaining feedback, they only did such as making sure teachers' instruction and sharing about topics.

\section{While Writing}

In the while writing, there are some strategy categories that the researcher explored in bilingual students' writing performance such as:

\section{Content}

First, in content activities, most bilingual students did the same strategies. They wrote a common expression in their writing rather than using a difficult expression from the internet. Bilingual students such as \#W, \#Z, \#K, and \#R argued that they put common expression while writing the content. As \#K said, "I use popular words in my writing but it depends on the article and my condition". Student \#R also said that "I use the common word because it makes me easy".

The next question to explore students' writing content in delivering their point of view, those bilingual students did not have strong arguments whether they put contrary view or not in their writing content. In line with that, most of the bilingual students did not put contrary views because they only focused to write what was on their mind naturally unless thinking over about specific writing content.

It is explained by \#N, \#Z, \#K, and \#W, it added by giving a conditional statement, \#R said that "Yeah it depends on the topics".

Bilingual students sometimes on some occasions gave an example in their content explanation. Those who did this strategy are \#N, \#K, and \#Z. Besides, most of the bilingual students would stop their writing when they got stuck. They considered taking a rest and do not continue their writing for a reason that would be useless if they wrote without knowing what they want to write. Another option that they chose to solve their problem was looking for a reference and asking a classmate. Student \#K as bilingual argued that "I stop my writing first to avoid a mess. I relax". Meanwhile student \#W said that "I take silence for a moment". Then they continued their statement for solving the problem such as \#K preferred to browse material on the internet and $3 \mathrm{~W}$ considered asking classmate's help. 
Bilingual students attended to use online dictionaries specifically Google translate. They seldom used a manual dictionary because they assumed that it took a more long time and did not provide complete vocabularies.

Student \#Z mentioned that "I use Google translate. It is faster than using a dictionary that takes a long time." as one of the reasons using an online dictionary was profitable in the writing process for saving time.

One of a bilingual, student \#R ever used an application for checking grammar in reason it helped him to write properly. Student \#W stated that "I checked grammar and spelling automatically in Google translate."

The data showed bilingual students had similarities in the language used while writing. Both of them used Indonesia as the source language first for writing activity then they translated it into English as the target language.

According to bilingual students, the most important language features in writing was vocabulary. They said that vocabulary took the whole role in writing because it contained words. Although there were still bilinguals assumed that grammar reflected their writing performance.

\section{Organization}

Bilinguals changed their first writing organization. In the process of their writing, they made differences whether moving sentences or changing paragraph sequence. \#Z in the interview answered that, "Yes I have. I make scratch before real writing in another paper."

As a reason, they changed their first writing organization because they wrote in a draft. However, bilingual students attended to follow the generic structure of the text. In this case, recount text which has a generic structure such as orientation, event, and reorientation, would rather write it systematically. \#K said that, "I write based on the structure started from orientation, event, and reorientation. Yeah because we have to write systematically to become well structure."

The second issue that the researcher found was writing a draft. Almost of the bilingual students made writing draft. They wrote in another paper and still unwell structure, sequence, or organization. Therefore, it was relevant that bilinguals more paid attention to not have any mistakes and errors in their writing by making a scratch paper before real writing and frequently checking their writing.

Feedback

The data in the writing process for feedback strategies significantly have similarities in writing preparation. Bilingual students employed activities that involved someone else to give suggestions, corrections, or feedback. Bilingual students such as \#Z, \#N, \#K, and \#R asked someone's suggestion as like classmate, brother or parents. \#K said that, "Yes, I'm asking the task about recount text to Mujahid".

As prove an activity involving someone's feedback in the writing process. Therefore, it could be seen that in the writing process there was a different frequency of feedback strategies if compared with writing preparation. The activities were asking the teacher's instruction, discussing the topic, asking about the language used, and making sure their writing. It also mentioned in \#W's statement, "No, I just asking what means of something when I don 't understand". 


\section{Mechanics}

Bilingual students considered checking their writing performance at the end of the writing process. As stated by \#Z, "Yes I often do that when I finish my writing and before collecting".

\section{Revision}

In this writing strategy, it has some categories of writing strategy as like mentioned in previous. There are content, language, feedback, mechanics, and organization. Each of those categories has specific activities such as:

\section{Content}

Generic structure of event gives challenging to bilingual students to revise their writing harder than another. \#K and \#W thought that was because the event contains main information about something factual. Moreover, \#N and \#Z assumed that they frequently revised their writing because of their vocabulary choices.

Bilinguals preferred to choose the language as the reason they are mistaken rather than structure. It has the same reason with bilingual students that they less knowledge about the target language or English. Therefore, when they wrote a topic they attended to less understanding. It appeared in \#K's statement, "My problem is vocabulary miss because I always repeat the same vocabulary frequently. I'm confused about that. So, I prefer vocabulary to avoid repetition.

The next issue is doing the last checking and revising. Only bilingual students had a strong tendency for doing the last checking and revising because there are four of five students who did it. \#K said in an interview that, "Yes I check it because it's important. We have to know the punctuation as like comma and full stop position in order to understand easily". To make sure their writing result was clear before collecting it to their teacher, they frequently did the last checking even not merely revising.

There were some strategies that they conducted such as asking classmates or teachers, searching the internet, repeating to check, and revising their writing. Each bilingual student had different problem solving but it could be specified if they were not able to solve their problem in grammar and vocabulary by their strategy they would involve someone's help. It showed from \#W's statement that "Yes sometimes I'm not sure with my writing but I often ask my classmate for the certainty", and \#K "I check it to Google which is about spelling to make sure it is appropriate with dictionary”.

\section{Language used}

As usual bilingual students did checking and revising sentences which included a structure in those sentences themselves. Most of the bilingual students considered to check and revise the sentence and its structure. For instances in the case of bilingual students, dominantly did both checking and revising the sentence if there was an error in the structure or coherence as stated by \#K, "Not exactly like that miss, we only understand what writing tells about. So we don't need to know and revise detail the sentence. Yes, I often revise sentences in my writing because I always repeat the words." 


\section{Mechanics}

In mechanics, activities focused on checking the punctuation, spelling, citation, and reading aloud the writing result. Bilingual students did not pay attention to checking the mechanic's components as reported by \#R that:

"I don't because I often skip that", except \#K that stated "Yes I check it because it's important. We have to know the punctuation as like comma and full stop position in order to understand easily".

Feedback

In this feedback strategies mostly discussed checking and revising writing by involving someone else for instance classmates, teachers, or members of a family. Almost bilingual students when did revision they would involve or need someone's help. Based on the bilingual interview, \#K stated that, "No, I don't if it's only about writing but yes I do if it's related with spelling revision I ask my friends." and \#W argued that "I do it by myself first then If I don't know ask my friend. "Student \#Z declared that she ever asked her brother and $\# \mathrm{~N}$ did the same thing, she asked for help from her parents when she found the difficulties.

Another issue in feedback strategies is asking someone else to review students' writing either classmate or teacher. Bilingual students did not maximize to do reviewing. Bilingual was not dominant number only two students who predicted their selves as a reader whether their writing was readable or not. As mentioned in \#W's statement, "Yeah sometimes I'm afraid if my writing is not easy to understand." and \#N "Yeah, I think someone else as a reader to make it easy understand".

The last issue is checking and revising for the last before collecting their writing result. All of the bilingual students had the same answer in the interview. They said that to prefer doing directly revising if there was a still mistake after checking. They did not wait for revising a long time; they wanted to finish the writing task as soon as possible before collecting it to the teacher.

\section{Organization}

Most the bilingual students stated that they needed a paragraph guideline when they wrote recount text. To make their writing easier, they needed some information about how to write in each generic structure. It was stated by \#N and \#Z that, "Yes it makes my writing easier".

It could be seen based on the findings of writing strategies, bilingual students were preventive to write carefully and collaboratively by making a draft, writing scratch before real writing, asking for teachers' instruction, and others. Furthermore, they did not give attention to the readers' perspective; and they were concerned to edit words or sentences instead of revising the content or organization of the text in each strategy such as preparation, while writing and revision. 


\section{The Dominant Strategies Used By Bilingual Students and The Reasons Why Used it}

The researcher obtained the data of bilingual students dominant strategies based on the students' interview showed that:

\section{Preparation Strategies}

The dominant sub-strategy in preparation was content. Almost all bilingual students employed the activities before their writing such as: making a draft and using Indonesia to translate into English. They did those activities because; they worried to make mistakes by preventing them in a draft and using Indonesia first rather than English. It was stated by \#W, \#R, \#K, and \#Z as bilingual.

\section{While Writing}

The dominant strategy was content. They did some activities in dominant number frequency such as: using a common expression, putting contrary view, giving an example in explanation, stop writing when getting stuck and looking for reference and asking classmate when do not know what they write. The reasons why bilingual students paid attention more to those activities while writing are: to make their writing becomes enjoyable and make them easy to conduct writing, and to help find the ideas about what they writing.

\section{Revision Strategies}

Bilingual students were focused on feedback as the dominant that contained some activities such as: getting teachers or classmate's feedback, needing direct oral feedback, and directly doing the last reviewing. They attended to do those activities in revision because: they sometimes did word repetition, forgot the event, revise spelling and pronunciation, did not sure about what they wrote that was why asked their classmate, and they needed direct feedback because it was clear to review.

\section{CONCLUSION}

Bilingual students' writing performance considered they were less aware of the organization and content of their writing. They are frequently concerned about the structure and spelling. Furthermore, the findings of writing strategies, bilingual students in each strategy of preparation, while writing and revision were preventive to write carefully and collaboratively by making a draft, writing scratch before real writing, asking teacher's instruction and others. Furthermore, they did not give attention to the readers' perspective; and they were concerned to edit words or sentences instead of revising the content or organization of the text in each strategy such as preparation, while writing and revision. It noted that the dominant strategy in preparation and while writing is related to content activities meanwhile in revision strategies are related to feeding activities.

\section{REFERENCES}

Abdul-Rahman, S. S. (2011). An investigation into the english academic writing strategies employed by students of he in the ne of england: with particular reference to their nationalities and gender. $P Q D T$ - UK \& Ireland, (April). 
Adesope, O. O., Lavin, T., Thompson, T., \& Ungerleider, C. (2010). A Systematic Review and Meta-Analysis of the Cognitive Correlates of Bilingualism. Review of Educational Research, 80(2), 207-245.

Bialystok, E., Luk, G., \& Kwan, E. (2005). Bilingualism, Biliteracy, and Learning to Read: Interactions Among Language and Writing Systems. Scientific _ Studies of Reading, 9(1), 17-42. https://doi.org/10.1207/s1532799xssr0901

Bialystok, E., McBride-Chang, C., \& Luk, G. (2005). Bilingualism, language proficiency, and learning to read in two writing systems. Journal of Educational Psychology. https://doi.org/10.1037/0022-0663.97.4.580

Bialystok, E. (2008). Second-language acquisition and bilingualism at an early age and the impact on early cognitive development. Encyclopedia on Early Childhood Development,1-4. Canada: York University

Bialystok, E., Luk, G., Peets, K. F., \& Yang, S. (2009). Receptive vocabulary differences in monolingual and bilingual children. Bilingualism:Language and Cognition, 13(04), 525531.https://doi.org/10.1017/s1366728909990423

Cenoz, J.; Gorter, D. \& Aiestaran, J. (2010) The linguistic landscape in multilingual schools. Paper Third International Linguistic Landscape Workshop. Strasbourg 5-7 May, 2010

Cenoz, J., \& Gorter, D. (2011). Focus on Multilingualism: a Study of Trilingual Writing. The Modern Language Journal, 95, 3, 356-369 DOI: 10.1111/j.1540-4781.2011.01206.x

Cummins, J. (2001). Teaching for Cross-Language Transfer in Dual Language Education: Possibilities and Pitfalls. Journal of Research in Childhood Education, 67(2), 1-8. https://doi.org/10.1017/CBO9781107415324.004

Davidson, C., 2007. Independent writing in current approaches to writing instruction: What have we overlooked?. English Teaching: Practice and Critique, [e-journal] 6 (1), pp. 1124.

Davidson, D., Raschke, V. R., \& Pervez, J. (2010). Syntactic awareness in young monolingual and bilingual (Urdu-English) children. Cognitive Development. 25(2), 166-182 doi:10.1016/j.cogdev.2009.07.003

Fu, D. \& Matoush, M. (2006). Writing development and biliteracy. In P.K. Matsuda, C. OrtmeierHooper, \& X. You (Eds.), The politics of second language writing: In search of the promised land (pp. 5-29). West Lafayette, Indiana: Parlor Press.

Geva, E., \& Siegel, L. S. (2000). Orthographic and cognitive factors in the concurrent development of basic reading skills in two languages. Reading and Writing, 12 (1-2), 130

Hoff, E., Core, C., Place, S., Rumiche, R., Senor, M., \& Parra, M. (2012). Dual language exposure and early bilingual development. Journal of Child Language, 39

Ivanova, I., \& Costa, A. (2008). Does bilingualism hamper lexical access in speech production? Acta Psychologica, $127,277-288$.

Leki, I., 2001. Material, Educational, and Ideological Challenges of Teaching EFL Writing at the Turn of the Century. IJES. 1(2), pp. 197-209. Available at: $<$ http://www.um.es/engphil/ijes>

Mohite, Miroslawa. (2014). An Investigation into the English Language Writing Strategies Used by Polish EFL Secondary School Learners.

Ng, E. (2015). Bilingualism , biliteracy and cognitive effects: A review paper. University of Sydney Papers in TESOL, 10, 93-128. 
Oller, D. K., \& Eilers, R. E. (2002). Language and literacy in bilingual children: Child language and child development. Clevedon: Multilingual Matters.

Sandoval, T. C., Gollan, T. H., Ferreira, V. S., \& Salmon, D. P. (2010). What causes the bilingual disadvantage in verbal fluency? The dual-task analogy. Bilingualism : Language and Cognition , 13 (2), 231-252.

Sugiharto, S. (2015). Impacts of Bilinguality on Students' Academic Writing Skill: Additional Evidence. Indonesian Journal of Applied Linguistics, 5(1), 61. https://doi.org/10.17509/ijal.v5i1.832

Sugiyono. (2017). Metode Penelitian Kuantitatif, Kualitatif dan R\&D. Bandung: Alfabet CV. 